\title{
Effect of starter cultures on properties of soft white cheese made from camel (Camelus dromedarius) milk
}

\author{
Birhanu Bekele, ${ }^{1 *}$ Egon B. Hansen, ${ }^{2}$ Mitiku Eshetu, ${ }^{3}$ Richard Ipsen, ${ }^{4}$ and Yonas Hailu ${ }^{3}$ \\ ${ }^{1}$ Yabello Pastoral and Dryland Agriculture Research Center, Oromia Agricultural Research Institute, PO Box 85, Yabello, Ethiopia \\ ${ }^{2}$ National Food Institute, Technical University of Denmark, 2800, Kgs. Lyngby, Denmark \\ ${ }^{3}$ School of Animal and Range Sciences, Haramaya University, PO Box 138, Dire Dawa, Ethiopia \\ ${ }^{4}$ Department of Food Science, University of Copenhagen, Rolighedsvej 30, 1958 Frederiksberg C, Denmark
}

\section{ABSTRACT}

This experiment was conducted to investigate the effect of starter cultures on the physicochemical properties, texture, and consumer preferences of soft white cheese (SWC) made from camel (Camelus dromedarius) milk. The experiment was laid out in a completely randomized design with 5 treatments [starter cultures; i.e., 1 thermophilic (STI-12), 2 blended (RST-743 and XPL2), and 2 mesophilic (R-707 and CHN-22) cultures]. Starter cultures STI-12 and RST-743 were inoculated at $37^{\circ} \mathrm{C}$, whereas XPL-2, R-707, and CHN-22 were inoculated at $30^{\circ} \mathrm{C}$. Camel milk inoculated using STI-12 and RST-743 cultures resulted in faster acidification than XPL-2, R-707, and CHN-22 cultures. Camel milk SWC made using STI-12 and CHN-22 cultures gave lower $\mathrm{pH}$ (4.54) and titratable acidity (0.59), respectively, whereas R-707 culture resulted in high cheese yield $(13.44 \mathrm{~g} / 100 \mathrm{~g})$. In addition, high fat $(20.91 \mathrm{~g} / 100$ $\mathrm{g})$, protein $(17.49 \mathrm{~g} / 100 \mathrm{~g})$, total solids (43.44 g/100 $\mathrm{g})$, and ash $(2.40 \mathrm{~g} / 100 \mathrm{~g})$ contents were recorded for SWC made from camel milk made using RST-743 culture. Instrumental analysis of cheese texture revealed differences in resistance to deformation in which camel milk SWC made using RST-743 culture gave higher firmness $(3.20 \mathrm{~N})$ and brittleness $(3.12 \mathrm{~N})$. However, no significant difference was observed among camel milk SWC adhesiveness made using different starter cultures. Consumer preference for appearance, aroma, taste, and overall acceptances of SWC were affected by inoculation of starter cultures. Considering curd firmness, cheese yield, compositional quality, and textures using STI-12, RST-743, and R-707, these cultures were found to be better for the manufacture of camel milk SWC.

Received May 19, 2018.

Accepted October 17, 2018.

*Corresponding author: birhanubekel@gmail.com
Key words: camel milk cheese, physicochemical, starter culture, taste preference, texture

\section{INTRODUCTION}

The camel (Camelus dromedarius) is considered a good source of milk (Siddig et al., 2016) and will produce milk for a longer time even during dry periods compared with cattle (Seifu, 2009). Camel milk contains all the vital nutrients found in bovine milk (Yagil, 1982). It has been stated that producing cheese from camel milk is difficult due to poor coagulation properties (Farah and Ruegg, 1989), weak curd (Ramet, 2001; Mehaia, 2006; El-Zubeir and Jabreel, 2008), and fragile and heterogeneous structure (Farah and Ruegg, 1989). Cheese yield is determined by the cheese curd and coagulum strength (Fox and McSweeney, 2004) and the nature of camel milk constituents influences the properties of cheese-making. The average size of casein micelles from camel milk are larger $(200-500 \mathrm{~nm})$ than those from cow milk (220-300 nm; Farah and Ruegg, 1989). The TS content of camel milk coagulum has been reported to be lower than from cow milk (especially casein; Ramet, 2001; Mehaia, 2006). The average size of fat globules from camel milk is smaller than those from cow milk (El-Zeini, 2006; Hailu et al., 2016b). The size of fat globules and the network formed with the milk fat globule membrane influence cheese yield (Horne and Banks, 2004). Camel milk can, however, be processed into cheese using camel chymosin (Kappeler et al., 2006; Hailu et al., 2016a) and addition of starter cultures for acidification.

Starter cultures are added to cheese milk for acidification through the production of lactic acid, resulting in a decrease in $\mathrm{pH}$, thus affecting several aspects of the cheese manufacturing process and finally cheese composition (Kongo, 2013). Appropriate acid production in terms of rate and time determines the activity of the coagulant, the microorganism's growth rate, coagulum strength, syneresis of the gel, solubility of colloidal calcium phosphate, cheese yield, and conse- 
quently the rheological property of the final cheese (Lucey et al., 2003; Fox and McSweeney, 2004). Moreover, the cultures added can also help in production of important aroma compounds such as diacetyl in fresh cheese (Urbach, 1997; Parente and Cogan, 2004) and acetaldehyde (Urbach, 1997). Diacetyl imparts a buttery aroma to cheese (Cogan, et al., 2007). Research on the manufacturing of cheese from camel milk using different starter cultures is limited, and the effects of these starter cultures on the final quality of camel milk cheese are largely unknown. However, a few trials have focused on evaluation of cheese from camel milk by direct acidification of milk and using starter cultures of lactic acid bacteria (Khan et al., 2004), manufacture of fresh soft white cheese (SWC; Domiati type) (Mehaia, 2006), and investigation of physicochemical properties and consumer acceptability of soft unripened cheese (Hailu et al., 2014). Camel milk is reported to be slow to acidify due to the presence of relatively higher concentration and activity of inhibitory substances (antimicrobial activity; El-Agamy et al., 1992). It has recently been demonstrated, however, that the bottleneck causing slow acidification is limited proteolysis of camel milk proteins by the starter cultures rather than inhibitory substances found in camel milk (Berhe et al., 2018).

It could be useful to identify different lactic acid bacteria species, including both mesophilic and thermophilic bacteria, that are able to grow in camel milk, as it is important to have strains for rapid development of lactic acid to reduce $\mathrm{pH}$ (Fugl et al., 2017). The effects of different starter cultures on the final properties of camel milk cheese are poorly understood. Understanding the effect of different starter cultures and characterizing the final product are vital for further development of appropriate cheese products from camel milk. This research was conducted to evaluate the properties of SWC made from camel milk using different commercial starter cultures.

\section{MATERIALS AND METHODS}

\section{Materials}

Pooled camel milk samples were collected from 10 camels from parity 2 to 5 and originating from 4 camelrearing pastoralists in Erer valley of the Babile district in Eastern Ethiopia. The milk was collected by directly milking into milking equipment and was transported within 1 to $2 \mathrm{~h}$ to Haramaya University and then stored at $4 \pm 11^{\circ} \mathrm{C}$ until use. Pooled camel milk samples of 25 $\mathrm{L}$ were collected at 2 separate sampling times. Recombinant camel chymosin had a concentration of 1,000 international milk clotting units/L. Starter cultures contained both defined and blended aroma-producing strains (i.e., CHN-22 and XPL-2) and single as well as blended non-aroma-producing strains (i.e., STI-12, R-707, and RST-743) of lactic acid bacteria. Both camel chymosin and commercial starter cultures were donated by Chr. Hansen A/S (Hørsholm, Denmark). All chemicals used were analytical grade and obtained from Sigma-Aldrich (Munich, Germany). Doubledistilled water was used for dilution of the chymosin.

\section{Milk Composition}

Protein, lactose, fat, and TS of the raw milk were analyzed using a Milkoscan FT1 (Foss, Hillerød, Denmark). The $\mathrm{pH}$ of the milk was measured using a calibrated electronic digital pH meter (model Starter 2100, Ohaus, Parsippany, NJ). The composition of raw camel milk used was $6.60 \pm 0.02(\mathrm{pH}), 0.09 \pm 0.01 \%$ (titratable acidity), $2.36 \pm 0.15 \mathrm{~g} \cdot 100 \mathrm{~g}^{-1}$ (protein), $3.47 \pm$ $0.28 \mathrm{~g} \cdot 100 \mathrm{~g}^{-1}$ (fat), $11.37 \pm 0.86 \mathrm{~g} \cdot 100 \mathrm{~g}^{-1}$ (TS), and $0.64 \pm 0.04 \mathrm{~g} \cdot 100 \mathrm{~g}^{-1}$ (ash). The results were in the previously published range (Konuspayeva et al., 2009).

\section{Cheese Making}

Soft white cheese was prepared from camel milk according to the method described by Hailu et al. (2018). Twenty-five liters of camel milk was divided into 5 parts of $5 \mathrm{~L}$ each, and 5 trials of soft cheese-making were conducted separately using 5 different commercial starters. The whole milk was filtrated using muslin cloth, and then each milk sample was pasteurized at $65^{\circ} \mathrm{C}$ for 30 min using a thermostatically controlled Buch and Hold waterbath (model WNB 45, Memmert $\mathrm{GmBH}+$ Co. Kg., Büchenbach, Germany). For cooling, pasteurized milk was transferred to cold water in an open plastic pan, adjusted to 37 and $30^{\circ} \mathrm{C}$, and transferred to an Armfield FT20 cheese vat (Armfield Ltd., Ringwood, UK) of 10-L capacity for curd making.

In the cheese vat, calcium chloride $(0.02 \mathrm{~g} / 10 \mathrm{~L}$ of milk) was added into the milk 30 min before the addition of the starter culture. Cooled milk was inoculated with starter culture as per inoculation temperature of the treatments. For inoculation of cultures, one bag of commercial culture of $50 \mathrm{U}$ was dissolved in $500 \mathrm{~mL}$ of fresh double-boiled $\left(100^{\circ} \mathrm{C}, 30 \mathrm{~min}\right)$ camel milk. After the contents were completely dispersed, this was poured into $250-\mathrm{mL}$ bottles and stored at $-20^{\circ} \mathrm{C}$ until use. The culture activity unit from the manufacturer was used to prepare the inoculum. Camel milk was inoculated with 2.0 units of starter culture per $10 \mathrm{~L}$ (a double dose compared with manufacturer's recommendation for 
cow milk). The STI-12 and RST-743 cultures were inoculated at $37^{\circ} \mathrm{C}$, whereas R-707, XPL-2, and CHN-22 cultures were inoculated into camel milk at $30^{\circ} \mathrm{C}$. The coagulant (camel chymosin) was diluted to a 1:9 ratio using double-distilled water before inoculation. After 30 min of starter culture addition (or more, depending on the time until a $\mathrm{pH}$ value of $\approx 6.25$ was reached), camel chymosin at a concentration of 85 international milk clotting units/L was inoculated to the acidified cheese milk according to the recommendation by Hailu et al. (2016a). The cheese milk was left undisturbed for approximately $2 \mathrm{~h}$ for coagulation at each corresponding starter culture inoculation temperature. Then, the curd was sliced into $2-\mathrm{cm}$ cubes using a sterile knife and held for $15 \mathrm{~min}$ for whey separation. The whey drainage was performed by pouring the cheese curd into a plastic mold lined with a cheese cloth. For further drainage of whey, the curd was placed in the mold for $24 \mathrm{~h}$ at 18 to $20^{\circ} \mathrm{C}$. The cheese samples were collected in sterile sealed plastic containers and kept in a refrigerator at $4^{\circ} \mathrm{C}$ for further analysis. Two batches of cheese from each treatment were made separately and analyzed.

\section{Composition of Soft White Cheese}

The composition ( $\mathrm{pH}$, titratable acidity, fat, protein, TS, and ash) of camel milk SWC was analyzed following standard procedures (AOAC International, 1995). A portion of cheese sample was sliced from the cheese block and blended using a mortar and pestle. Cheese was sampled according to protocol of Ardö and Polychroniadou (1999). The fat content of $3 \mathrm{~g}$ of cheese sample was analyzed using Gerber method. The protein content of $5 \mathrm{~g}$ of cheese sample was determined using the Kjeldahl method. The TS and ash contents of $5 \mathrm{~g}$ of cheese samples were measured using the gravimetric method (AOAC International, 1995). Cheese $\mathrm{pH}$ and titratable acidity were measured on the same day the cheese was manufactured, the other parameters within $48 \mathrm{~h}$. Composition analysis of the cheese samples was performed in duplicate.

\section{Cheese Yield}

The obtained cheese was weighed immediately before storage using a digital weighing balance. The weight of the cheese sample was recorded, and the yield of the cheese was calculated as follows:

$$
\text { cheese yield } \%=\frac{\text { weight of cheese }}{\text { weight of milk }} \times 100 \text {. }
$$

\section{Texture Analysis of Soft White Cheese}

Cheese texture analysis was performed using TA-TX Plus micro stable texture analyzer (Micro Stable Micro Systems Ltd., Golborne, Warrington, UK), following the procedure stated by Wium et al. (1997). A cylindrical sample of $20 \mathrm{~mm}$ height and $18 \mathrm{~mm}$ diameter was prepared by slowly punching vertically using a lubricated borer at $5^{\circ} \mathrm{C}$. The cheese samples were conditioned at the measuring temperature, $13^{\circ} \mathrm{C}$, for at least $1 \mathrm{~h}$ before testing. The exterior of the cheese was not used, and care was taken to keep the handling temperature below the test temperature. The compression test was performed with a speed of $0.83 \mathrm{~mm} / \mathrm{s}$ and a $30-\mathrm{kg}$ load cell. The upper and lower compression plates, made of stainless steel, were lubricated with low-viscosity oil. The cheese samples were compressed to $50 \%$ of their original height. Parameters such as firmness (i.e., mean maximum positive force), brittleness (i.e., mean force where the curve is broken up during the first bite), and adhesiveness (mean maximum negative force) were extracted from the texture analyzer exponent software to evaluate the texture properties of cheese samples.

\section{Consumer Preference Test of Soft White Cheese}

Consumer preference tests for variables such as color, appearance, aroma, taste, and overall acceptance were carried out by 12 trained sensory evaluators. The evaluation was identified using a 7 -point hedonic scale $(1=$ dislike extremely, $2=$ dislike moderately, $3=$ dislike slightly, $4=$ neither like nor dislike, $5=$ like slightly, 6 = like moderately, and $7=$ like extremely). Each experimental cheese sample was coded and provided to evaluators after $24 \mathrm{~h}$ of manufacturing. The evaluation was conducted independently, and the evaluators rinsed their mouths with warm water and had a break for about $20 \mathrm{~s}$ between testings. The evaluations of consumer preference for all cheese samples were conducted on the same day.

\section{Statistical Analysis}

Experimental design of physicochemical, textures, and consumer preference test scored data were analyzed using the ANOVA technique of completely randomized design with 5 treatments. All treatment means were compared using a Student $F$-test at $\alpha=0.05$ and separated by the least significant difference method. The model to determine a fixed effect to fit the data was

$$
Y_{i j}=\mu+c_{i}+e_{i j},
$$


Table 1. Composition of commercial starter cultures

\begin{tabular}{lll}
\hline Culture & Type $^{1}$ & Composition \\
\hline STI-12 & Thermophilic & Streptococcus thermophilus \\
RST-743 & Blended & Lactococcus lactis and Streptococcus thermophilus \\
R-707 & Mesophilic & Lactococcus lactis without biovar diacetylactis \\
XPL-2 & Blended & $\begin{array}{l}\text { Lactococcus lactis } \text { ssp. cremoris, Lactococcus lactis } \text { ssp. lactis, Lactococcus lactis } \text { ssp. lactis biovar } \\
\text { diacetylactis, Leuconostoc species, and Streptococcus thermophilus }\end{array}$ \\
CHN-22 & Mesophilic & $\begin{array}{l}\text { Lactococcus lactis } \text { ssp. cremoris, Leuconostoc pseudomesenteroides, Lactococcus lactis ssp. lactis biovar } \\
\text { diacetylactis, Lactococcus lactis ssp. lactis, and Leuconostoc mesenteroides }\end{array}$ \\
\hline
\end{tabular}

${ }^{1}$ Blended $=$ mixture of mesophilic and thermophilic cultures.

where $Y_{i j}=$ the value of measurement observed on processed cheese, $\mu=$ the overall mean, $c_{i}=$ the culture effect, and $e_{i j}=$ the random error.

\section{RESULTS AND DISCUSSION}

\section{Acidification Process of Camel Milk}

Table 1 indicates the type and composition of the starter cultures used. The acidification rate of different starter cultures to $\mathrm{pH} \approx 6.25$ is indicated in Table 2 . The result showed that camel milk inoculated with STI-12 and RST-743 cultures resulted in a faster acidification rate than that inoculated with XPL-2 and CHN-22 cultures. Camel milk inoculated with the R-707 culture had an intermediate acidification rate.

Starter cultures with slower acidification rates resulted in weaker cheese curd. Consequently, curds from camel milk inoculated with XPL-2 and CHN-22 cultures were difficult to transfer from the cheese vat to the mold, and most of the fine grains were lost in the whey. The variations in acidification time and $\mathrm{pH}$ values may be attributed to difference among starter cultures in rate and intensity of acidification. According to Kongo (2013), in cheese-making, the rate of acidification of milk through the production of lactic acid, with a consequent decrease in $\mathrm{pH}$, depends on the type of starter cultures used.

\section{Composition of Soft White Cheese}

The acidity, $\mathrm{pH}$, yield, and contents of fat, protein, TS, and ash of SWC made from camel milk using 5 commercial starter cultures are summarized in Table 3. Significant $(P<0.05)$ differences were observed between starter cultures. Cheese made with STI-12 starter culture and inoculated at $37^{\circ} \mathrm{C}$ resulted in lower $\mathrm{pH}$ values than SWC made with $\mathrm{CHN}-22$ culture inoculated at $30^{\circ} \mathrm{C}$. No significant difference $(P>0.05)$ was found in camel milk SWC pH made using R-707, XPL-2, and CHN-22 cultures (Table 3). The $\mathrm{pH}$ found in the current study is generally lower than the values (5.27) reported by Hailu et al. (2014) for camel milk soft unripened cheese made using Streptococcus thermophilus culture and camel chymosin.

In accordance with this, a higher titratable acidity (1.09\% expressed as lactic acid) of camel milk SWC was also obtained when using STI-12 culture and the lowest $(0.59 \%)$ was found when using CHN-22 culture. The latter value is in agreement with Hailu et al. (2014), who reported a value of $0.57 \%$ titratable acidity for soft unripened camel milk cheese made using Streptococcus thermophilus culture and camel chymosin. The variation in the $\mathrm{pH}$ and acidity values of camel milk SWC samples is most probably due to the inoculation of different commercial starter cultures for acidification. The rate of acid formation in the milk can be varied and is

Table 2. Acidification rate of camel milk using different commercial starter cultures ${ }^{1}$

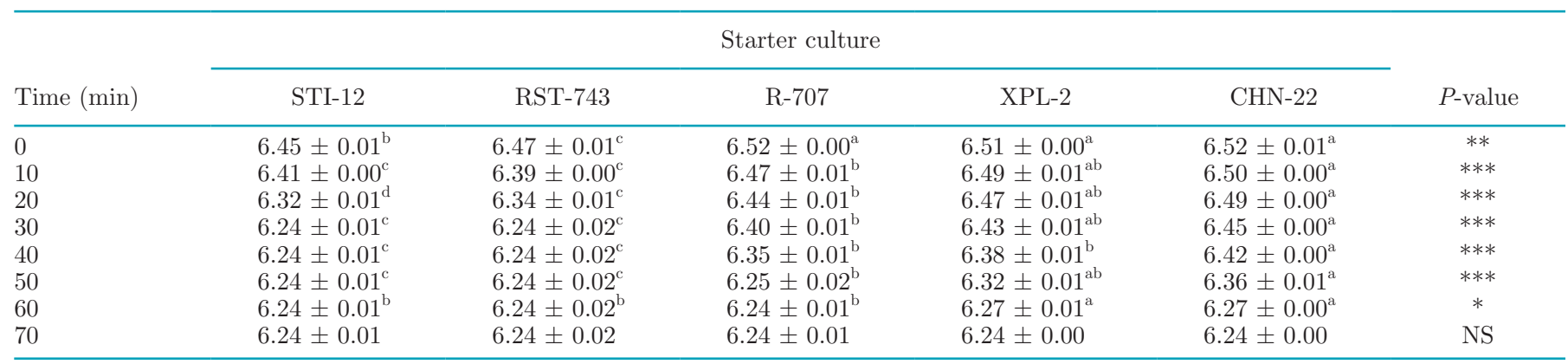

${ }^{\mathrm{a}-\mathrm{d}}$ Means with different superscripts within the same row are significantly $(P<0.05)$ different.

${ }^{1} \mathrm{pH}$ values in the table are mean $\pm \mathrm{SD}$ of $\mathrm{n}=2$. STI-12 and $\mathrm{RST}-743$ were inoculated at $37^{\circ} \mathrm{C}$, whereas R-707, XPL-2, and CHN-22 cultures were inoculated at $30^{\circ} \mathrm{C}$ for manufacturing of soft white cheese from camel milk.

${ }^{*} P<0.05 ; * * P<0.01 ; * * * P<0.001$. 
Table 3. Physicochemical properties (g/100 g unless otherwise indicated) of soft cheese made from camel milk

\begin{tabular}{|c|c|c|c|c|c|c|}
\hline Parameter & \multicolumn{5}{|c|}{ Starter culture } & $P$-value \\
\hline pH & $4.54 \pm 0.17^{\mathrm{c}}$ & $4.76 \pm 0.12^{\mathrm{bc}}$ & $5.04 \pm 0.12^{\mathrm{ab}}$ & $4.92 \pm 0.05^{\mathrm{ab}}$ & $5.20 \pm 0.06^{\mathrm{a}}$ & * \\
\hline Yield & $9.43 \pm 1.85^{\mathrm{b}}$ & $9.77 \pm 0.98^{\mathrm{b}}$ & $13.44 \pm 0.09^{\mathrm{a}}$ & $10.18 \pm 0.27^{\mathrm{b}}$ & $9.50 \pm 0.34^{\mathrm{b}}$ & $*$ \\
\hline Fat & $18.71 \pm 0.56^{\mathrm{b}}$ & $20.91 \pm 0.82^{\mathrm{a}}$ & $18.89 \pm 0.76^{\mathrm{b}}$ & $17.99 \pm 0.45^{\mathrm{b}}$ & $18.74 \pm 0.57^{\mathrm{b}}$ & * \\
\hline Protein & $16.29 \pm 0.11^{\mathrm{a}}$ & $17.49 \pm 1.73^{\mathrm{a}}$ & $12.18 \pm 0.10^{\mathrm{b}}$ & $16.33 \pm 0.55^{\mathrm{a}}$ & $11.12 \pm 0.02^{\mathrm{b}}$ & $* *$ \\
\hline
\end{tabular}

${ }^{\mathrm{a}-\mathrm{d}}$ Means with different superscripts within the same row are significantly $(P<0.05)$ different.

${ }^{1}$ Values in the table are mean \pm SD. STI- 12 and RST-743 were inoculated at $37^{\circ} \mathrm{C}$, whereas R-707, XPL-2, and CHN-22 cultures were inoculated at $30^{\circ} \mathrm{C}$ for manufacturing of soft white cheese from camel milk.

$* P<0.05$ and ${ }^{* *} P<0.01$.

dependent on the activity of the culture added (Walstra et al., 2006).

Significantly $(P<0.05)$ higher cheese yield $(13.44$ $\mathrm{g} / 100 \mathrm{~g})$ was obtained for cheese made using R-707 culture (Table 3$)$. Low cheese yield $(9.50 \mathrm{~g} / 100 \mathrm{~g})$ and higher moisture content were observed for SWC made using CHN-22 culture. This could be due to the very weak cheese curd obtained with this slow-acidifying culture, resulting in higher loss of fine curd particles through the pores of the cheese cloth during whey drainage. The yield obtained when using R-707 is similar to the result of Khan et al. (2004), who reported $13.2 \%$ yield from camel milk fresh SWC using a starter culture.

Significantly $(P<0.05)$ higher fat $(\mathrm{g} / 100 \mathrm{~g})$ content was recorded for cheese made using RST-743 (20.19) compared with STI-12 (18.71), R-707 (18.89), XPL-2 (17.99), and CHN-22 (18.74) cultures. Several factors may be responsible for these variations of cheese fat; among others, the rheological and micro-structural properties of gels' strength and the higher curd loss from the cheese vat resulted in excess whey fat loss (Castillo, 2006). The values of camel milk SWC fat in the current experiment made using STI-12, RST-743, R-707, XPL-2, and CHN-22 cultures are higher than the results of Mehaia (2006) who reported $16.91 \%$ cheese fat made from whole camel milk. However, these results are in line with the findings of Khan et al. (2004), who reported $19.00 \%$ fat of fresh cheese. Conversely, Siddig et al. (2016) reported a drastically lower fat value $(3.85 \%)$ for camel whole milk cheese.

The protein content of SWC was significantly $(P<$ 0.05 ) affected by the type of starter culture used for cheese making, meaning that a cheese made with STI12 , RST-743, and XPL-2 had a significantly $(P<0.05)$ higher protein value $(\mathrm{g} / 100 \mathrm{~g}): 16.29,17.49$, and 16.33 , respectively. The protein content of camel milk SWC made using all cultures in this experiment is lower than the findings of Khan et al. (2004) who reported $21.30 \%$ protein for camel milk cheese; however, a protein content of $14.81 \%$ was reported for fresh SWC made from camel milk (Mehaia, 2006).

Higher TS (i.e., $43.44 \mathrm{~g} / 100 \mathrm{~g}$ ) of camel milk SWC $(P<0.01)$ were recorded from SWC made using RST743 culture than that obtained using R-707 (35.77) and CHN-22 (34.76) cultures. The TS content found in camel milk SWC made using STI-12 (40.40) and XPL$2(38.54)$ cultures was similar to the value of $39.90 \%$ found by Hailu et al. (2014). Ramet (2001) reported that for soft camel milk cheese made using bovine rennet, 35 to $45 \%$ TS was observed at the end of draining. The variation of TS incorporated into the cheese might be attributed to the original milk composition and processing condition of cheese manufacture. Most of the components making up the TS, such as protein and fat, are progressively concentrated into the cheese curd according to cheese processing and the method used to drain the whey. In addition to the milk clotting effect, the acidification process plays a key role in eliminating the colloidal minerals of the casein micelles, coagulant retention in the curd, syneresis of the gel, coagulum strength, and cheese yield (Lucey et al., 2003; Fox and McSweeney, 2004). The final solubility level of calcium and phosphorus determines the draining rate of the curd and, in turn, the TS content of the cheese (Ramet, 2001).

Significantly $(P<0.05)$ lower ash content $(1.27$ $\mathrm{g} / 100 \mathrm{~g}$ ) was observed in camel milk SWC made using CHN-22 culture. The higher ash content $(2.40 \mathrm{~g} / 100 \mathrm{~g})$ of SWC made using RST-743 culture was in line with the report of Siddig et al. (2016), who found 2.36\% ash in camel milk cheese. On the other hand, the ash content of camel milk cheese made using RST-743 culture was higher than the $1.98 \%$ ash of camel milk unripened cheese indicated in the report of Hailu et al. (2014), which used Streptococcus thermophilus starter culture for acidification. Many factors may be responsible for these cheese ash variations: for instance, the nature 
of the ingredients used in the cheese-making process, the ash content of the raw material used (Hailu et al., 2014), and the addition of salt during cheese manufacturing (Mehaia, 2006). Hence, the variation observed could be due to the variation in starter culture used for acidification. The method of cheese manufacturing can result in the observed variation, as both Khan et al. (2004) and Siddig et al. (2016) used a direct acidification method involving the addition of citric acid.

\section{Texture Analysis of Soft White Cheese}

In Figure 1, the compression curves of force versus time for camel milk SWC are shown. We observed that camel milk SWC made using the RST-743 culture resulted in higher resistance to deformation compared with cheese made using STI-12, R-707, XPL-2, or CHN-22 cultures. However, camel milk SWC made using XPL-2 and CHN-22 cultures had lower deformation values than that made from camel milk using STI-12, RST-743, and R-707 cultures. Camel milk SWC made using cultures RST-743 and STI-12 had lower moisture and higher TS contents, which might explain the higher resistance to deformation compared with the soft cheese made from camel milk using R-707, XPL-2, and CHN-22 cultures.

Camel milk SWC made with XPL-2 culture had a moisture value similar to that made with STI-12 culture and a protein value similar to cheese made with RST-743 and STI-12 cultures. However, unlike other cheeses, the SWC made with XPL-2 underwent extensive syneresis during storage, which may be the reason for its low resistance to deformation. It has previously been shown that the moisture contents of a cheese

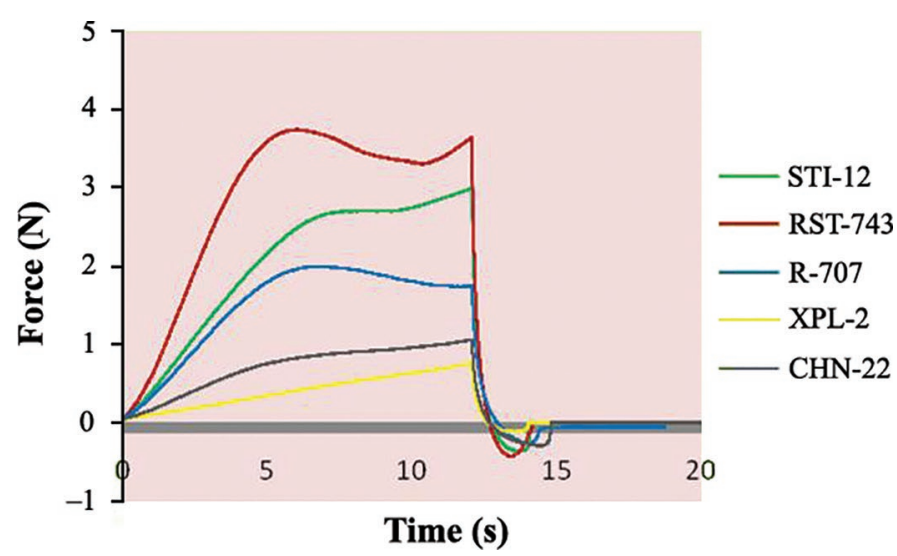

Figure 1. Compression curves of soft white cheese (SWC) made from camel milk using different starter cultures Compression values from a single replication are shown from the texture analyzer software. The STI-12 and RST-743 cultures were inoculated at $37^{\circ} \mathrm{C}$, whereas R-707, XPL-2, and CHN-22 cultures were inoculated at $30^{\circ} \mathrm{C}$. affect its texture characteristics; cheese samples with lower moisture contents show resistance to deformation (Guinee et al., 2001; Lucey et al., 2003; Bongiolo et al., 2014). Walstra et al. (2006) reported that the curd formation process is influenced by acidification, which affects cheese $\mathrm{pH}$ and casein matrix hydration. The firmness of the cheese curd increases with a reduction in $\mathrm{pH}$ (Lucey et al., 2003).

Camel milk SWC made using different cultures showed a variation in cheese texture properties (i.e., firmness and brittleness; Figures 2 and 3). The result indicated that camel milk SWC made using RST-743 culture had significantly higher firmness $(3.2 \mathrm{~N} ; P$ $<0$. 0.01) and brittleness $(3.12 \mathrm{~N} ; P<0.05)$ values than camel milk SWC made using XPL-2 $(0.75,0.4 \mathrm{~N})$ and CHN-22 $(0.96,0.74 \mathrm{~N})$ cultures, respectively. No significant difference was observed in cheese adhesiveness among the camel milk SWC made using different starter cultures.

Acidification of cheese milk during cheese manufacturing resulted in a drop in $\mathrm{pH}$ that affected the moisture content and consequently the mineral content of the cheese curd (Fox and McSweeney, 2004). This has been attributed to the extent of swelling of casein sub-micelles with the increase in casein-to-moisture ratio. Consequently, even small variations in moisture content can have significant effects on the cheese texture of fresh cheese (Gunasekaran and Mehmet, 2002). In addition to these, Guinee et al. (2001) investigated the effects of fat content on cheese microstructure and texture. They explained that increases in fat content result in smoother and softer cheese, and increases in casein content result in firmer cheese. It was also found that higher fat and water contents tend to weaken the

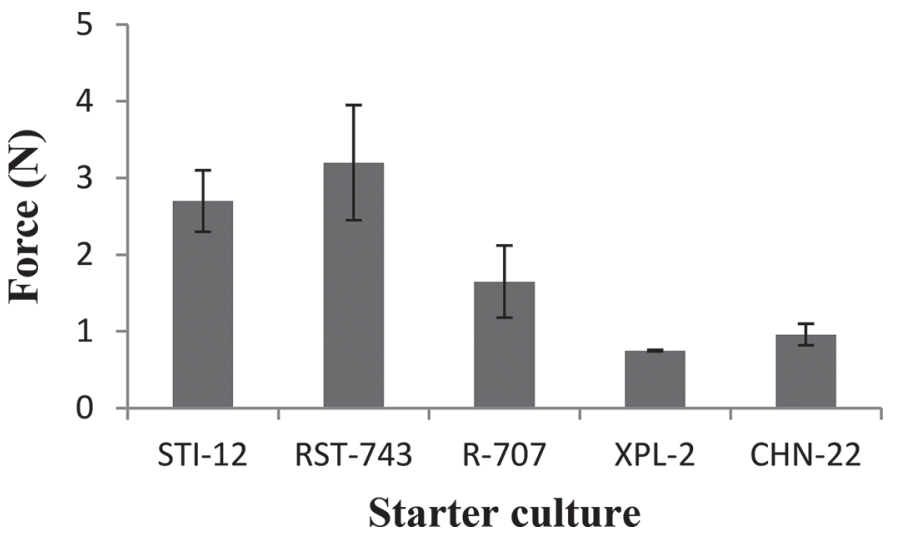

Figure 2. Firmness of soft white cheese (SWC) made from camel milk using different starter cultures. Firmness values are mean \pm SD. STI-12 and RST-743 = camel milk SWC made using culture STI-12 and RST-743 at $37^{\circ} \mathrm{C}$, respectively. R-707, XPL-2, and CHN-22 = camel milk SWC made using R-707, XPL-2, and CHN-22 culture at $30^{\circ} \mathrm{C}$, respectively. 
Table 4. Consumer preference test scores for soft white cheese made from camel milk ${ }^{1}$

\begin{tabular}{|c|c|c|c|c|c|c|}
\hline Parameter & \multicolumn{5}{|c|}{ Starter culture } & $P$-value \\
\hline Color & $6.66 \pm 0.49$ & $6.75 \pm 0.45$ & $6.50 \pm 0.52$ & $6.66 \pm 0.65$ & $6.66 \pm 0.49$ & NS \\
\hline Aroma & $5.16 \pm 0.38^{\mathrm{b}}$ & $5.08 \pm 0.51^{\mathrm{b}}$ & $4.83 \pm 0.57^{\mathrm{b}}$ & $6.25 \pm 0.62^{\mathrm{a}}$ & $6.58 \pm 0.51^{\mathrm{a}}$ & $* * *$ \\
\hline Taste & $4.83 \pm 0.83^{\mathrm{b}}$ & $4.91 \pm 0.51^{\mathrm{b}}$ & $4.66 \pm 0.51^{\mathrm{b}}$ & $6.16 \pm 0.57^{\mathrm{a}}$ & $6.41 \pm 0.51^{\mathrm{a}}$ & $* * *$ \\
\hline Overall acceptance & $6.08 \pm 0.51^{\mathrm{a}}$ & $6.00 \pm 0.42^{\mathrm{ab}}$ & $5.80 \pm 0.38^{\mathrm{ab}}$ & $4.16 \pm 0.57^{\mathrm{c}}$ & $5.58 \pm 0.79^{\mathrm{b}}$ & $* * *$ \\
\hline
\end{tabular}

${ }^{a-c}$ Means with different superscripts within a row are significantly $(P<0.05)$ different.

${ }^{1}$ Values in the table are mean \pm SD. STI- 12 and RST-743 were inoculated at $37^{\circ} \mathrm{C}$, whereas R-707, XPL-2, and CHN-22 cultures were inoculated at $30^{\circ} \mathrm{C}$ for manufacturing of soft white cheese from camel milk. Seven-point hedonic scale: $1=$ dislike extremely; $2=$ dislike moderately; $3=$ dislike slightly; $4=$ neither like nor dislike; $5=$ like slightly; $6=$ like moderately; and $7=$ like extremely.

$* * * P<0.001 ;$ NS: $P>0.05$.

protein structure of the cheese, as well as its texture (Fox et al., 2017).

\section{Consumer Preference Test of Soft White Cheese}

Significant differences $(P<0.05)$ were observed for consumer preference test scores except for those concerning color (Table 4). Camel milk SWC made using XPL-2 culture had lower scores for appearance $(P<$ $0.001)$ and overall acceptance $(P<0.001)$ than that of SWC made using STI-12, RST-743, R-707, and CHN22 cultures. On the other hand, camel milk soft cheese made using XPL-2 and CHN-22 cultures had higher $(P$ $<0.001)$ scores for aroma and taste as compared with camel milk SWC made using STI-12, RST-743, and R-707 cultures.

The variations in flavor could be attributed to the inherent properties of the starter cultures XPL-2 and

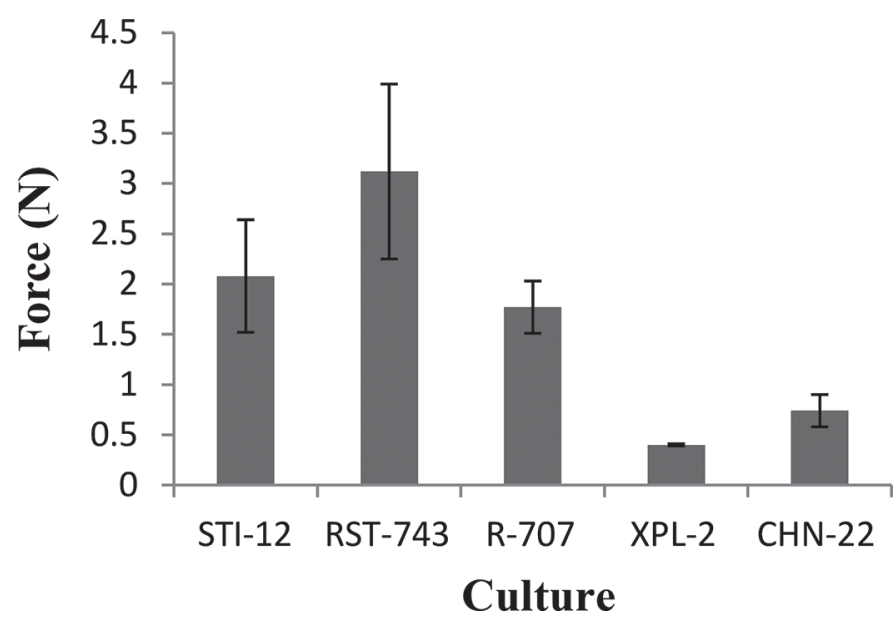

Figure 3. Brittleness of soft white cheese (SWC) made from camel milk using different starter cultures. Brittleness values are mean \pm SD. STI-12 and RST-743 = camel milk SWC made using culture STI12 and RST-743 at $37^{\circ} \mathrm{C}$, respectively. R-707, XPL-2, and $\mathrm{CHN}-22=$ camel milk SWC made using R-707, XPL-2, and CHN-22 culture at $30^{\circ} \mathrm{C}$, respectively.
CHN-22 in production of aroma compounds such as diacetyl. Diacetyl is naturally produced by lactic acid bacteria, especially Lactococcus lactis biovar diacetylactis, from citrate in co-fermentation with lactose in the production of several cheese (Papagianni, 2012).

The variations in consumer preference test scores in this study, particularly in appearance, aroma, taste, and overall acceptance of the cheese samples, might be attributed to the properties of the different commercial starter cultures used. Moreover, compounds such as $\mathrm{CO}_{2}$, diacetyl, and acetaldehyde might have contributed the development of distinct textural and flavor properties in the cheese (Walstra et al., 2006; Papagiannni, 2012).

\section{CONCLUSIONS}

The starter cultures used in this experiment showed a considerable effect on physicochemical, texture, and consumer preferences regarding SWC made from camel milk. Camel milk treated with nonaromatic cultures such as STI-12, RST-743, and R-707 for SWC manufacture showed a rapid acidification rate and formation of appreciable fine curd properties. As a result, camel milk SWC made using nonaromatic cultures gave better curd firmness, cheese compositional quality, and texture. However, aromatic (XPL-2 and CHN-22) cultures resulted in better consumer preference scores for taste and aroma. The addition of a starter culture to camel milk facilitates camel milk coagulation by increasing the lactic acid content and improving curd firmness; in this process, the properties of the cheese curd determine the quality of the final cheese product. Commercial nonaromatic starter cultures were better than aromatic cultures in terms of acidification time, curd firmness, cheese yield, compositional quality, and texture of cheese. Therefore, nonaromatic starter cultures are the preferred cultures in the manufacturing of camel milk SWC. In addition, the combination of both aromatic and nonaromatic culture could be used 
for SWC making; however, the possible additive effect needs confirmation study.

\section{ACKNOWLEDGMENTS}

The authors thank the Danish International Development Agency (DANIDA) for financial support via the Haramaya Camel Dairy Project, grant number 12017DTU, coordinated by Egon Bech Hansen, Technical University of Denmark (Kgs. Lyngby, Denmark).

\section{REFERENCES}

AOAC International. 1995. Official Methods of Analysis, 15th ed. AOAC International, Washington, DC.

Ardö, Y., and A. Polychroniadou. 1999. Laboratory manual for chemical analysis of cheese. European Communities, Office for Official Publications of the European Communities, Luxembourg.

Berhe, T., R. Ipsen, E. Seifu, M. Y. Kurtu, M. Eshetu, and E. B. Hansen. 2018. Comparison of the acidification activities of commercial starter cultures in camel and bovine milk. LWT Elsevier. 89:123-127.

Bongiolo, R., E. Schwinden, C. B. Fritzen-freire, M. Penteaodo, A. Silvio, and H. Daguuer. 2014. Rheological, physicochemical and authenticity assessment of Minas Frescal cheese. Food Control 45:22-28.

Castillo, M. 2006. Cutting time prediction methods in cheese making. In Encyclopedia of Agricultural, Food, and Biological Engineering. Taylor \& Francis, Abingdon, UK. https://doi.org/10.1081/E -EAFE-120040365.

Cogan, T. M., T. P. Beresford, J. Steele, J. Broadbent, N. P. Shah, and Z. Ustunol. 2007. Invited review. Advances in starter cultures and cultured foods. J. Dairy Sci. 90:4005-4021.

El-Agamy, E. I., R. Ruppanner, A. Ismail, C. P. Champagne, and R. Assaf. 1992. Antibacterial and antiviral activity of camel milk protective proteins. J. Dairy Res. 59:169-175.

El-Zeini, H. M. 2006. Microstructure, rheological and geometrical of fat globules of milk from different animal species. J. Food Nutr. Sci. 15:147-154.

El-Zubeir, I. E. M., and M. S. O. Jabreel. 2008. Fresh cheese from camel milk coagulated with Camifloc. Int. J. Dairy Technol. 61:90-95.

Farah, Z., and M. W. Ruegg. 1989. The size distribution of casein micelles in camel milk. Food Microstructure 8:211-216.

Fox, P. F., T. P. Guinee, T. M. Cogan, and P. L. H. McSweeney. 2017. Cheese: Structure, Rheology and Texture. In: Fundamentals of Cheese Science. Springer, Boston, MA.

Fox, P. F., and P. L. H. McSweeney. 2004. Cheese: An overview. Pages 1-18 in Cheese Chemistry, Physics and Microbiology. P. F. Fox, P. L. H. McSweeney, T. M. Cogan, and T. P. Guinee, ed. Elsevier Academic Press, London, UK.

Fugl, A., T. Berhe, K. Kiran, S. Hussain, M. F. Laursen, M. I. Bahl, Y. Hailu, K. I. Sørensen, M. Eshetu, R. Ipsen, and E. B. Hansen. 2017. Characterisation of lactic acid bacteria in spontaneously fermented camel milk and selection of strains for fermentation of camel milk. Int. Dairy J. 73:19-24.

Guinee, T. P., E. P. Feeney, and P. F. Fox. 2001. Effect of ripening temperature on low moisture Mozzarella cheese: 2. Texture and functionality. Lait 81:475-485.

Gunasekaran, S., and A. K. Mehmet. 2002. Cheese Rheology and Texture. 1st ed. Taylor and Francis Group, CRC Press, Boca Raton, FL.

Hailu, Y., E. B. Hansen, E. Seifu, M. Eshetu, and R. Ipsen. 2016a. Factors influencing the gelation and rennetability of camel milk using camel chymosin. Int. Dairy J. 60:62-69.
Hailu, Y., E. B. Hansen, E. Seifu, M. Eshetu, R. Ipsen, and S. Kappeler. 2016b. Functional and technological properties of camel milk proteins: A review. J. Dairy Res. 83:422-429.

Hailu, Y., E. B. Hansen, E. Seifu, M. Eshetu, M. A. Petersen, R. Lametsch, F. Rattray, and R. Ipsen. 2018. Rheological and sensorial properties and aroma compounds formed during ripening of soft brined cheese made from camel milk. Int. Dairy J. 81:122-130.

Hailu, Y., E. Seifu, and Z. Yilma. 2014. Physicochemical properties and consumer acceptability of soft unripened cheese made from camel milk using crude extract of ginger (Zingiber officinale) as coagulant. Afr. J. Food Sci. 8:87-91.

Horne, D. S., and J. M. Banks. 2004. Rennet-induced Coagulation of Milk. P. F. Fox, P. L. H. McSweeney, T. M. Cogan, and T. P. Guinee, ed. Pages 47-70 in Cheese Chemistry, Physics and Microbiology. Elsevier Academic Press, London, UK.

Kappeler, S. R., H. J. van den Brink, H. Rahbek-Nielsen, Z. Farah, Z. Puhan, E. B. Hansen, and E. Johansen. 2006. Characterization of recombinant camel chymosin reveals superior properties for the coagulation of bovine and camel milk. Biochem. Biophys. Res. Commun. 342:647-654.

Khan, H., I. H. Athar, and M. Aslam. 2004. Evaluation of cheese by processing camel milk. Pak. J. Zool. 36:323-326.

Kongo, J. M. 2013. Lactic acid bacteria as starter-cultures for cheese processing: Past, present and future development. In Lactic Acid Bacteria. Intech, Croatia. https://doi.org/10.5772/55937.

Konuspayeva, G., B. Faye, and G. Loiseau. 2009. The composition of camel milk: A meta-analysis of the literature data. J. Food Compos. Anal. 22:95-101.

Lucey, J. A., M. E. Johnson, and D. S. Horn. 2003. Invited Review: Perspectives on the basis of the rheology and texture properties of cheese. J. Dairy Sci. 86:2725-2743.

Mehaia, M. A. 2006. Manufacture of fresh soft white cheese (Domiatitype) from dromedary camels milk using ultrafiltration process. J. Food Technol. 4:206-212.

Papagiannni, M. 2012. Metabolic engineering of lactic acid bacteria for the production of industrially important compounds. Comput. Struct. Biotechnol. J. 3:e201210003. https://doi.org/10.5936/csbj .201210003 .

Parente, E., and T. M. Cogan. 2004. Starter Cultures: General Aspects. Pages 123-149 in Cheese Chemistry, Physics and Microbiology. P. F. Fox, P. L. H. McSweeney, T. M. Cogan, and T. P. Guinee, ed. Elsevier Academic Press, London, UK.

Ramet, J. P. 2001. The technology of making cheese from camel milk (Camelus dromedarius). Animal Production and Health, FAO, Rome, Italy.

Seifu, E. 2009. Analysis on the contributions of and constraints to camel production in Shinile and Jigjiga zones, eastern Ethiopia. J. Agric. Environ. Int. Dev. 103:213-224.

Siddig, S. M., A. M. E. Suliman, Z. A. Salih, and A. A. Abdelmuhsin. 2016. Quality characteristics of white cheese (Jibna-beida) produced using camel milk and mixture of camel milk and cow milk. Int. J. Food Sci. and Nutrition Eng. 6:49-54.

Urbach, G. 1997. The flavour of milk and dairy products: 11. Cheese: Contribution of volatile compounds. Int. J. Dairy Technol. 50:79 89.

Walstra, P., J. T. M. Wouters, and T. J. Geurts. 2006. Dairy Science and Technology. 2nd ed. Taylor and Francis Group, CRC Press, Boca Raton, FL.

Wium, H., M. Gross, and K. B. Qvist. 1997. Uniaxial compression of uf-feta cheese related to sensory texture analysis. J. Texture Stud. $28: 455-476$.

Yagil, R. 1982. Camels and camel milk. FAO Animal Production and Health. Paper No. 26. Food and Agriculture Organization, Rome, Italy. 